the Federal Republic of Nigeria. Its objective is to assist the development efforts of low-income Regional Member Countries whose economic and social conditions and prospects require concessional financing.

Official languages: English and French.

Headquarters: Immeuble du Centre de Commerce International d'Abidjan CCIA, Avenue Jean-Paul II, 01 BP 1387, Abidjan 01, Côte d'Ivoire.

Website: http://www.afdb.org

Email: afdb@afdb.org

President: Akinwumi Adesina (Nigeria).

\section{African Export-Import Bank (Afreximbank)}

Established in 1987 under the auspices of the African Development Bank to facilitate, promote and expand intraAfrican and extra-African trade. Membership is made up of three categories of shareholders: Class 'A' Shareholders consisting of African governments, African central banks and sub-regional and regional financial institutions and economic organizations; Class ' $B$ ' Shareholders consisting of African public and private financial institutions; and Class ' $C$ ' Shareholders consisting of international financial institutions, economic organizations and non-African states, banks, financial institutions and public and private investors.

Official languages: English, French, Arabic and Portuguese.

Headquarters: 72B El Maahad El Eshteraky St., Heliopolis,

Cairo 11341, Egypt.

Website: http://www.afreximbank.com

President and Chairman of the Board: Benedict Okey Oramah (Nigeria).

\section{African Union (AU)}

History. The Fourth Extraordinary Session of the Assembly of the Heads of State and Government of the Organization of African Unity (OAU) held in Sirté, Libya on 9 Sept. 1999 decided to establish an African Union. At Lomé, Togo on 11 July 2000 the OAU Assembly of the Heads of State and Government adopted the Constitutive Act of the African Union, which was later ratified by the required two-thirds of the member states of the Organization of African Unity (OAU); it came into force on 26 May 2001. The Lusaka Summit, in July 2001, gave a mandate to translate the transformation of the Organization of African Unity into the African Union, and on 9 July 2002 the Durban Summit, in South Africa, formally launched the African Union.

Members. Algeria, Angola, Benin, Botswana, Burkina Faso, Burundi, Cabo Verde, Cameroon, Central African Republic, Chad, Comoros, Democratic Republic of the Congo, Republic of the Congo, Côte d'Ivoire, Djibouti, Egypt, Equatorial Guinea, Eritrea, Ethiopia, Gabon, Gambia, Ghana, Guinea, Guinea-Bissau, Kenya, Lesotho, Liberia, Libya, Madagascar, Malawii, Mali, Mauritania, Mauritius, Mozambique, Namibia, Niger, Nigeria, Rwanda, Sahrawi Arab Democratic Republic (Western Sahara), São Tomé e Príncipe, Senegal, Seychelles, Sierra Leone, Somalia,
South Africa, South Sudan, Sudan, Swaziland, Tanzania, Togo, Tunisia, Uganda, Zambia, Zimbabwe.

Aims. The African Union aims to promote unity, solidarity, cohesion and co-operation among the peoples of Africa and African states, and at the same time to co-ordinate efforts by African people to realize their goals of achieving economic, political and social integration.

Activities. The African Union became fully operational in July 2002, and is working towards establishing the organs stipulated in the constitutive act. These include a Pan-African parliament, an Economic, Social and Cultural Council (ECOSOCC) and a Peace and Security Council (which have now been inaugurated), plus a Central Bank (which has not yet been launched).

The African Court on Human and Peoples' Rights was established in 2004. A protocol to set up an African Court of Justice entered into force in 2009, but has been superseded by a plan to create an African Court of Justice and Human Rightsalso incorporating the Court on Human and Peoples' Rightswhich had yet to come to fruition as of Feb. 2016. Supporters of the proposal hope that this court will eventually supplant the International Criminal Court in prosecuting human rights abuses in Africa.

The African Union has established several peacekeeping forces, including in Burundi (2003-04), the Darfur region of Sudan (initially from 2004, and as part of a hybrid AU-UN mission since 2007), Somalia (since 2007) and the Central African Republic (since 2013).

Official languages: Arabic, English, French, Portuguese, Spanish and Swahili.

Headquarters: POB 3243, Roosevelt St. (Old Airport Area),

W21K19 Addis Ababa, Ethiopia.

Website: http://www.au.int

Chairman: Idriss Déby (Chad).

Chair of the African Union Commission: Nkosazana DlaminiZuma (South Africa).

\section{Further Reading}

Makinda, Samuel M., and Okumu, F. Wafula, The African Union: Challenges of Globalization, Security, and Governance. 2007

Miller-Jones, Edward R., The African Union: Aiming to Unify the Continent. 2010

Muthri, Tim, Akopari, John and Ndinga-Mavumba, Angela, (eds.) The African Union and its Institutions. 2008

New Zealand Ministry of Foreign Affairs and Trade, African Union Handbook 2015. 2015

Welz, Martin, Integrating Africa: Decolonization's Legacies, Sovereignty and the African Union. 2012

\section{Bank of Central African States (BEAC)}

The Bank of Central African States (Banque des Etats de l'Afrique Centrale) was established in 1973 when a new Convention of Monetary Co-operation with France was signed. The five original members, Cameroon, Central African Republic, Chad, Republic of the Congo and Gabon, were joined by Equatorial Guinea in 1985. Under its Convention and statutes, the BEAC is declared a 'Multinational African institution in the management and control of which France participates in return for the guarantee she provides for its currency'.

Official language: French.

Headquarters: 736 avenue Monseigneur Vogt, 1917 Yaoundé,

Cameroon.

Website (French only): http://www.beac.int

Governor: Lucas Abaga Nchama (Equatorial Guinea). 